\title{
Rainwater Harvesting Systems in Australia
}

\author{
M. van der Sterren ${ }^{1,2}$, A. Rahman ${ }^{1}$ and G.R. Dennis ${ }^{1}$ \\ ${ }^{1}$ University of Western Sydney, \\ ${ }^{2}$ NSW Office of Environment and Heritage, \\ Australia
}

\section{Introduction}

The Australian continent has an extremely variable climate, as a result of the different oceanic currents and atmospheric variation. Australia has regular cycles of droughts and floods resulting in highly variable storage volumes in its major dams. The population in Australia is nearly 23 million (Australian Bureau of Statistics (ABS), 2011) of which the majority lives in the South-East coast of Australia. The largest cities (see Figure 1) are Sydney (4.58 million people.), Melbourne (4.08 million people), Brisbane (1.07 million people) and Canberra $(358,600$ people) (ABS, 2011). The water supply storage for these cities is located in the nearby mountain ranges and brought to the metropolitan areas through large distribution water pipes. The urban fringe areas, rural locations and the outback have limited reticulated water supply and often rely on capturing roof water, farm dam water and bore water for their water supply. The roof water in these regions provides the principal potable water supply, whilst farm dam and bore water are often used to meet non-potable requirements and for livestock (ABS, 2010). Historically, this has been different in the urban areas where potable and non-potable supply demands are met with a reticulated water supply.

A shift has occurred in the Australian Water industry as a result of population growth, the worst drought in living memory (Horstman, 2007) and a desire to become more sustainable. Total Water Cycle Management has gained momentum in Australia and new property developments must consider all aspects of the water cycle, including water supply, waste water treatment, stormwater control and water quality control of all discharges and supplies (Argue, 2004; Argue \& Pezzaniti, 2009; Barton \& Argue, 2009; Hardy, 2009; Hardy et al., 2003; Wong, 2006b, c; Wong et al., 2008; Wong \& Brown, 2009). Rainwater tanks are being installed in urban areas, resulting in an increase resilience of the cities to droughts and a reduction of mains water demand. These rainwater tank installations are encouraged in various Development Control Plans (DCPs), through state legislation, such as the NSW Building and Sustainability Index (BASIX Sustainability Unit, 2009), and by providing rebates (Blacktown City Council, 2006; Blue Mountains City Council, 2005; Gardiner \& Hardy, 2005; Ku-ring-gai Council, 2005; Penrith City Council, 2010). The reasons for installing a rainwater tank in Australia include reducing mains water costs, helping the environment, irrigating the garden and because it was mandatory when the house was built (ABS, 2010; Blackburn et al., 2010; White, 2010). 


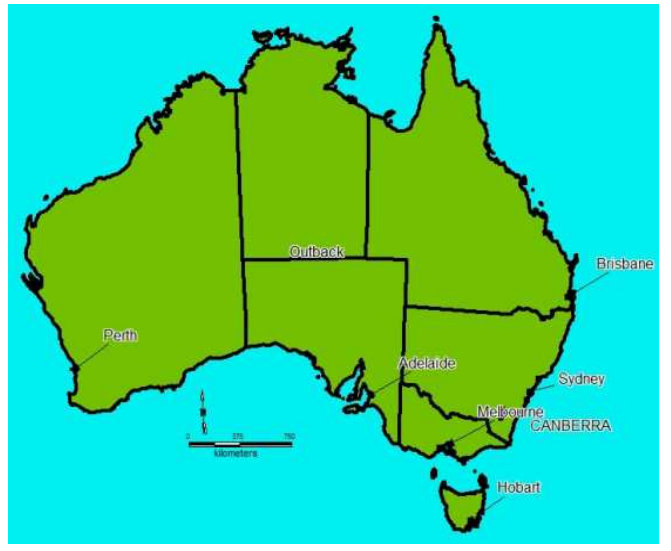

(a)

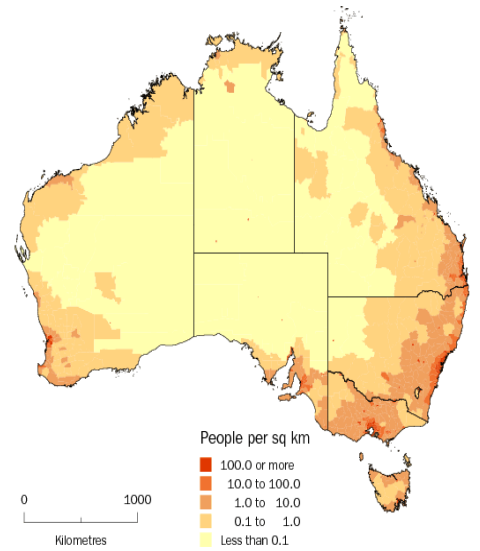

(b)

Fig. 1. Australia with the location of major urban centres (a) and Population density (b) (ABS, 2011)

\section{Legislation}

\subsection{Australian guidelines}

The water quality requirements in Australia have been developed using a fit-for-purpose approach. The guidelines for water quality in Australia are supported by the Department of Sustainability, Environment, Water, Population and Communities of the Australian Commonwealth Government. The Natural Resource Management Ministerial Council (NRMMC) released the guidelines and, in some cases, with input from the National Health and Medical Research Council (NHMRC) and the Australian Health Ministers Conference. These National Councils update and publish a number of guidelines applicable to rainwater tank installation in Australia. These guidelines are discussed below and are dependent on the point of discharge, users, use and general application of the water in the rainwater tank. The guidelines are summarised below:

- $\quad$ Australian and New Zealand guidelines for fresh and marine water quality (AFWG) (Australian and New Zealand Environment and Conservation Council \& Agriculture and Resource Management Council of Australian and New Zealand (ANZECC \& ARMCANZ), 2000a, b);

- $\quad$ Australian drinking water guidelines (ADWG) (NHMRC \& NRMMC, 2004);

- Guidelines for urban stormwater management (ANZECC \& ARMCANZ, 2000c); and

- Australian guidelines for water recycling: managing health and environmental risks Phase 2 (NRMMC et al., 2009c), including

- Australian Guidelines for Water Recycling: Stormwater Harvesting and Reuse (NRMMC et al., 2009a) or Recycled Water Guidelines (RWG); and

- Australian Guidelines for Water Recycling: Augmentation of Drinking Water Supplies (NRMMC et al., 2009b). 


\subsection{Stormwater harvesting and reuse}

Stormwater harvesting and reuse guideline have been prepared as part of the National Water Quality Management Strategy (NWQMS) by NRMMC, Environment Protection and Heritage Council (EPHC) and the NHMRC (2009a). The guideline uses a risk-based approach to stormwater harvesting and can be adopted for any stormwater harvesting technique. The management and treatment techniques for the harvested stormwater depend on the type of catchment area (roof, drainage system, driveway) and its intended end-use (potable, non-potable or irrigation only). The guideline has a specific section for the management of harvested roof water and identifies these systems as low risk. In particular, the guideline indicated that roof water harvesting for residential dwellings should meet the criteria and management techniques specified in the Australian Standards (AS) (Standards Australia, 2008) and Guidance on use of rainwater tanks (enHealth Council, 2004). For nonresidential buildings or for a larger user group (nursing homes), the stormwater harvesting guideline (NRMMC et al., 2009a) is recommended to be applied and a risk assessment is to be conducted for the proposed end-uses of the rainwater harvesting system

The end-uses for harvested roof water are also dependent on other guidelines and policies. Most council Development Control Plans (DCP) specify that water from a rainwater tank is not to be used for drinking (Blue Mountains City Council, 2005; Hawkesbury City Council, 2000; Upper Parramatta River Catchment Trust (UPRCT) et al., 2005) even though the New South Wales (NSW) Department of Health does not prohibit its use. The NSW Department of Health does recommend using the water only for non-potable purposes when town water is available (enHealth Council, 2004; Environmental Health Branch, 2008). In contrast to this, it was concluded by Heyworth, Maynard \& Cuncliffe $(1998$, p. 9) that 'little is known about the associated health risks' in regards to using water from a rainwater tank. It should be noted that a large number of Australians still rely on their rainwater tank as their sole supply of drinking water. They are advised by various government bodies to refer to Cuncliffe (1998) and enHealth (2004) to determine how to maintain a rainwater tank and how to improve the quality of drinking water from their rainwater tank.

In addition to these guidelines, the Australian Standards (AS) specify how these systems should be constructed. The AS 3500 (Standards Australia, 2006) specifies connections, backflows prevention systems and roof gutter design. The handbook (Standards Australia, 2008) shows how the systems can be designed and constructed to ensure a low risk, high quality fit-for-purpose water supply. In Australia, all designs and constructions of roof water harvesting and drainage systems need to adhere to minimum standard specified in the Australian Standards. Stormwater harvesting can also be used augment drinking water supplies and the guideline divides the augmentation of drinking water supplies in direct augmentation and indirect augmentation (NRMMC et al., 2009b). Indirect augmentation includes storages, such as dams or rivers prior to treatment and distribution. Direct augmentation includes storages such as rainwater tanks and recycled water treatment plants and requires the treatment and adequate management of the system to protect users.

\subsection{Australian Drinking Water Guidelines}

The Australian Drinking Water Guidelines (NHMRC \& NRMMC, 2004) give the minimum standards to which water supply authorities need to treat drinking water to protect the 
users, especially those who are very young, elderly or immuno-compromised. Rainwater tanks on private property are not required to meet these guidelines for low risk use. A risk assessment approach is recommended for larger harvesting systems to ensure the risk associated with the use of the rainwater is managed (NRMMC et al., 2009a). Adopted management techniques can include fit-for-purpose use of the harvested water or treating the harvested water to the ADWG (NHMRC \& NRMMC, 2004).

\subsection{Fresh and marine water quality guidelines}

The AFWG (ANZECC \& ARMCANZ, 2000a, b) are used to determine objectives for in stream water quality of fresh and marine waters from high conservation areas to heavily modified systems. The overflow from harvesting systems is commonly directly diverted to the receiving waters through a drainage system. So although the AFWG (ANZECC \& ARMCANZ, 2000a, b) are ambient in-stream water quality objectives, it is important to understand the impact that rainwater tank overflows might have on the receiving waters. Mixing of flows will occur within the drainage system thereby affecting the final concentrations of the water quality parameters.

\subsection{Stormwater management}

The current guideline for stormwater quality, Australian Guidelines for Urban Stormwater Management (ANZECC \& ARMCANZ, 2000c) is based on a risk management approach, which is appropriate for catchment wide management, but difficult to implement on a lot scale. Council-wide assessments are made by local councils to develop a stormwater management plan. These plans have been developed by some councils and Catchment Management Authorities to identify management scenarios and pollutant hot spots, and are developed to reduce the pollutant levels in the run-off discharges from the catchment. Some councils have implemented water quality targets or water quality objectives for new developments, based on published water quality targets (see Table 1).

\begin{tabular}{|l|l|}
\hline Pollutant & Percentage Detained \\
\hline Suspended Solids & $80 \%$ retention of average load \\
\hline Total Phosphorus & $45 \%$ retention of average annual load \\
\hline Total Nitrogen & $45 \%$ retention of average annual load \\
\hline Litter & Retention of litter $(>50 \mathrm{~mm})$ up to the 3-month ARI peak flow \\
\hline Coarse Sediment & Retention of sediment $(>0.125 \mathrm{~mm})$ up to the 3-month ARI peak flow \\
\hline Oil and Grease & No visible oils up to the 3 month ARI peak flows \\
\hline
\end{tabular}

Table 1. Guidelines for stormwater pollutant discharges (data from Wong, 2006, p. 1-6).

Water quality and quantity control for redevelopment in many council areas is required to include an On Site Detention system (OSD) and a trash rack in front of an orifice screen. This is often combined with an in-line commercial pollutant filter. The trash screen is a mesh screen bolted to the OSD pit wall to remove litter, vegetation and sediment (Nicholas, 1995).This screen removes the gross pollutants and may also trap other pollutants (Goyen et al., 2002; UPRCT2005). In most cases, a commercially available pollutant filter is added to the design to reduce the contaminants below the threshold values shown in Table 1. OSD systems by themselves may not be able meet the standards shown in Table 1. Brisbane City Council (2008) developed a framework for water quality requirements that can be 
specifically applied to a site, based on the urban stormwater point of discharge to the catchment (for example a specific stormwater outlet or receiving stream). Other councils such as Blacktown City Council (BCC) (2006) and Blue Mountains City Council (BMCC) (2005) require the designs to protect specific receiving waters and these councils refer designs to the respective Catchment Management Authorities (CMA).

Often council requirements do not take into consideration any improvement in discharge water quality as a result of rainwater tank on-site. A number of contrasting results have been reported in regard to the water quality of rainwater tank. Evans et al. (2006, p. 37) reviewed the current literature on water quality of rainwater tank and found that 'a clear consensus on the quality and health risks associated with rainwater has not been reached' for water use. Furthermore, research has also indicated that the internal processes in the rainwater tank, such as sedimentation and micro-layer flocculation, can improve the water quality in the tank (Spinks et al., 2003).

\section{Construction and typical Australian rainwater tanks}

The application and size of rainwater tanks in Australia is highly varied. The tanks come in all shapes and sizes, but are also made from different materials. Australian rainwater tanks are often constructed above ground (see Figure 2(a)), partially in-ground (see Figure 2(b)), inground (see Figure 2(c)) or under house and the tanks can be made of polypropylene (see Figure 2(a)), concrete (see Figure 2(b)), and coated corrugated iron (Zincalume ${ }^{\circledR}$, Colorbond ${ }^{\circledR}$ ) (see Figure 2(e)). The size of the tank is dependent on roof area, water demand, local rainfall characteristics, and availability of mains water including required security of supply. Each of these characteristics has a different effect on the size of the tank to meet demand (Barry \& Coombes, 2006, 2007; Coombes, 2002; Standards Australia, 2008). The size of the tank also has an impact on the materials used as the forces associated with water and ground pressure have a direct impact on the total stress on the tank wall (Standards Australia, 2008). The structural integrity of a large tank can be difficult to maintain for the polypropylene tanks (PVC) and therefore often concrete is used for larger tanks. The smaller tanks are often chosen for urban areas and need to be able to be installed in confined spaces, such as small side setbacks or little alcoves. The shape, size and general visual appeal of small tanks are therefore very different than the larger concrete tanks (Standards Australia, 2008). Finally, the cost of the tank material can often also become a deciding factor in the selection of size and material.

All rainwater tanks are required to have as an absolute minimum an inlet, an outlet to meet demand and an overflow point (see Figure 3). Rainwater tanks can also be fitted with a pump for ease of use (Standards Australia, 2008), a top-up system for areas where mains water is available (Barry \& Coombes, 2006, 2007; Standards Australia, 2008), a first flush (Cuncliffe, 1998; enHealth Council, 2004; Standards Australia, 2008) and a water treatment system (Föster, 1996; Standards Australia, 2008). Furthermore in some urban areas stormwater is also detained in the tank, adding a third outlet in the tank to separate detention $^{1}$ and retention ${ }^{2}$ of run-off from the roof. These additional items are dependent on

${ }^{1}$ Detention of run-off is to keep the water on the site for a period of time and slowly release the flow to the downstream system.

${ }^{2}$ Retention of run-off is to keep the water on the site for an unknown period of time and reuse the captured volume on the site. 
the local legislation, but a first flush is recommended to be installed everywhere to improve the water quality on the tank.



(a)



$(\mathrm{c})^{3}$

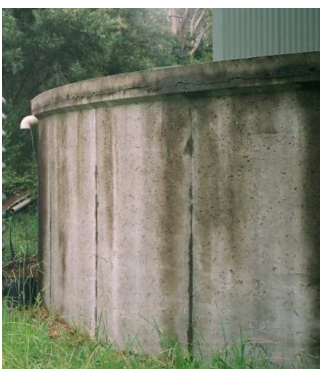

(b)

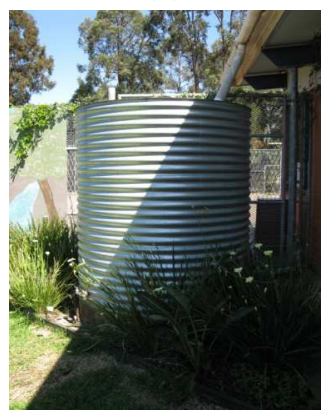

(e)

Fig. 2. Rainwater tank site locations and materials

In a rainwater tank study in Western Sydney, it was identified that topping-up of a rainwater tank with mains water can cause a change in the harvested water quality (van der Sterren et al., 2010a; 2009; 2010b). A larger value of hardness and conductivity was observed when mains water was added to the tank. The tank had reached a low volume as a result of high levels of water use and top-up of the water in the tank was needed. Mains water in the area has a typical value between 35 and $62 \mathrm{mg} \mathrm{L}^{-1} \mathrm{CaCO}_{3}$, which increased the hardness of water within the rainwater tank after, which created similar concentration in the tank as in the mains water supply (Sydney Water, 2007). The results were significantly higher than the average conductivity in the rainwater tank and the equilibrium was not re-established until 3 months after the mains water was added (see Figure 4).

A first-flush device diverts the first part of the run-off (e.g. first 5 minutes)and it is allowed to drain overland. Griffin et al. (1980) showed that the first $30 \%$ runoff generated by a storm has a higher contaminant concentration and contains nearly $70 \%$ of the total pollutant load. Bucheli et al. (1998) and Föster (1999) found that the run-off from the first $2 \mathrm{~mm}$ of rain contains most of the total pollutants on a number of different roof types. The remaining flows for the roofs have a lower contaminant concentration and are treated by the natural processes within the rainwater tank itself. Goonetilleke et al. (2005, p. 33) disagrees with

${ }^{3}$ Reproduced with permission from Rocla Pty Ltd (www.rocla.com.au) 
these findings as the first-flush is 'never precisely defined' and argued that the pollutant load, rather than the concentration, should be the governing factor for the design.

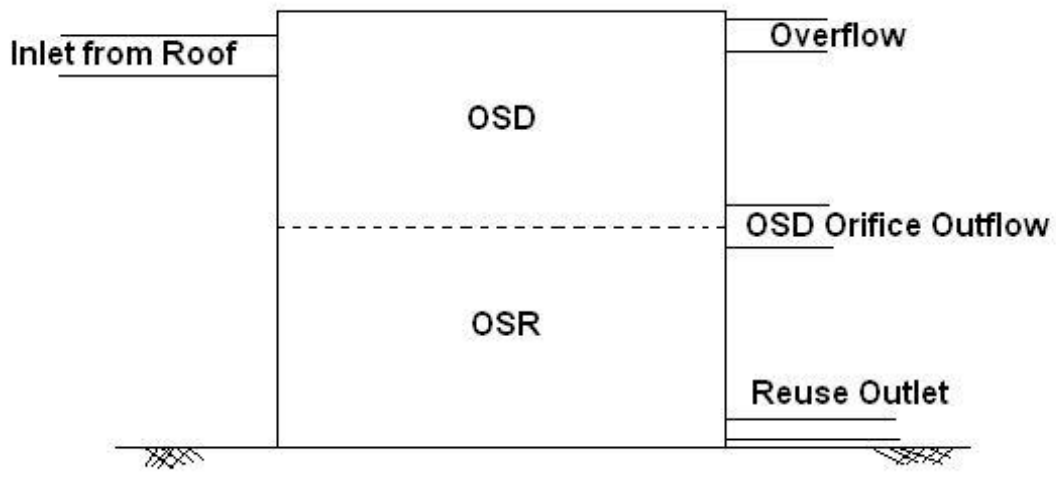

Fig. 3. Rainwater tank with inlet, overflow, outlet and optional third outlet for detention control.

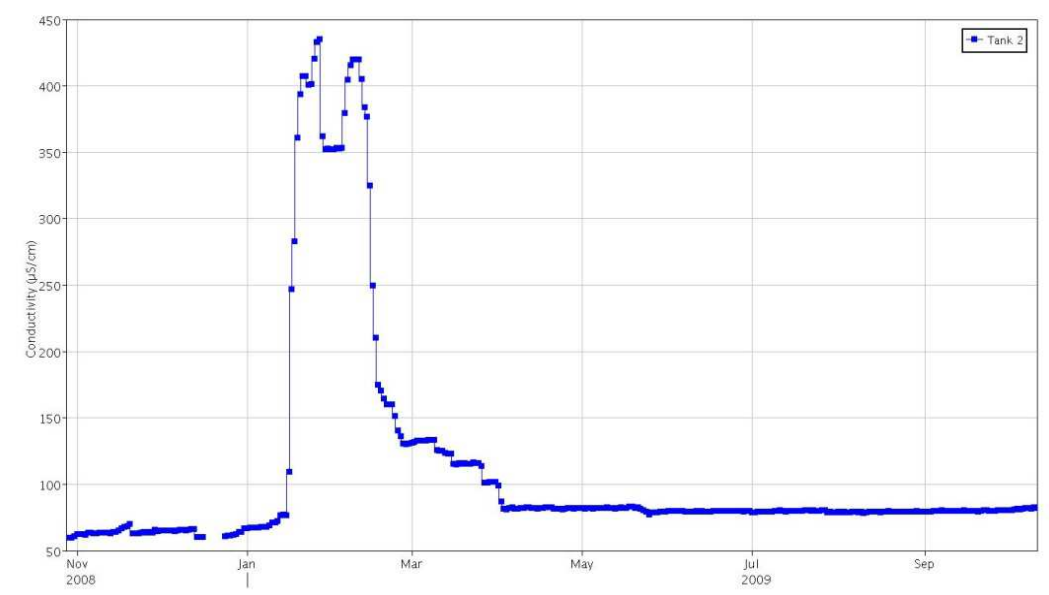

Fig. 4. Conductivity measurements for a rainwater tank in Western Sydney showing the effect of the mains water added to the tank.

Brodie (2007) indicated that the volume required for an effective first-flush is hard to quantify when duration of the storm event is similar to the time of concentration $\left(t_{c}\right)$ of the roof catchment and this can cause difficulties in designing a first-flush. Recently a new technique was suggested by Bach et al. (2010) to determine the first-flush based on statistical analysis of the concentration of pollutants in the first-flush versus the background concentrations rather than a set amount of rainfall as the criteria. This could provide a volume-based design approach suitable for industry application. The removal of pollutants by collecting the first-flush and separating it from the water in the rainwater tank can result in better water quality in the tank. Mendez et al. (2011), however, did not find a significant 
difference in the water quality in rainwater tank with or without a first-flush. A recent study in Western Sydney showed elevated levels of microbes, nutrients and heavy metals in the first-flush, which were significantly higher than the samples of the harvested water (van der Sterren et al., 2009; 2010b). In addition, the E.coli and Enterococcus enumeration exceeded secondary contact guidelines, which indicates that pathogens can be present in the firstflush. The data collected in the Western Sydney study supports the emptying of the firstflush after a storm event, which often is not conducted on a regular basis. This defeats the purpose of the system, highlighting the importance of having a first-flush device that can operate without human intervention, especially to prevent the inhalation of pathogens when cleaning is conducted. Recently some councils (e.g. Penrith City Council, 2008, 2010) have added the requirement to connect the overflow from the rainwater tank directly to the street drainage; recent research has found that the overflow quality is not significantly cleaner than the harvested tank water due to settlement of pollutants in the rainwater tank (van der Sterren et al., 2010a; 2009; 2010b). The impact of the overflow quality and comparison of overflow water quality to tank water quality is included in Section 4.2.

\section{Water quality of harvested water in Australia}

\subsection{Processes within the rainwater tank}

During storage of water in a rainwater tank, various chemical and biological processes take place. Well known processes are those of settlement and re-suspension of particles (Davis \& Cornwell, 2006), conservation of energy (Moeller et al., 1984; Young et al., 2004) and conservation of mass (Moeller et al., 1984). Each of these processes plays a vital role in improving the water quality in a rainwater tank and in turn ensures that the water in the tank ages and is purified through natural processes.

Settlement and the monolayer/multilayers at the air/liquid interface are two critical processes contributing to water quality in rainwater tanks (Spinks et al., 2003). The settlement could significantly reduce Total Solid (TS) concentrations in the overflow and tank water quality, whilst a biofilm and/or chemical gradients could potentially be critical contributors to overflow contamination. A number of pollutants have been shown to adhere to Suspended Solids (SS) and TS. The principal law that governs the settling of particles is known as Stoke's Law and is a function of particle size and gravitation forces through the medium (Davis \& Cornwell, 2006). The particle density and radius vary within the solution and are dependent on the pollution run-off characteristics. In Australia, the average particle size of SS is larger than $125 \mu \mathrm{m}$ (Melbourne Water, 2005). Miguntanna et al. (2010a; 2010b) found that the 75 to $150 \mu \mathrm{m}$ particle range had the strongest influence on the Total Nitrogen (TN) build-up, whilst the 1 to $150 \mu \mathrm{m}$ particle range had the strongest influence on the Total Phosphorous (TP) build-up. Brodie (2007), on the other hand, investigated sediment size and found that over $50 \%$ was smaller than $63 \mu \mathrm{m}$ in roof run-off. The particle density varies from $1600 \mathrm{~kg} \mathrm{~m}^{-3}$ for sand, $1720 \mathrm{~kg} \mathrm{~m}^{-3}$ for coarse materials and $1210 \mathrm{~kg} \mathrm{~m}^{-3}$ for organic fine sediment (Verkerk et al., 1992).

Previous research has found that the water quality at the surface of the water in a rainwater tank is significantly different from the water quality at the bottom of the rainwater tank (Coombes, 2002). This difference has been attributed to stratification. Stratification occurs in lakes and wetlands (Doods, 2002) and could occur in rainwater harvesting systems, which 
results in chemical and physical gradients in the water column. In addition, a biofilm can form on the air/liquid interface and the solid/liquid interface (Hermansson \& Dahlbäck, 1983; Hermansson et al., 1987; Marshall, 1980; Parker \& Barson, 1970; Percival et al., 2000; Sigee, 2005; Spinks et al., 2003). Stratification occurs in a body of water, due to warm water being less dense than cooler water. The mixed layer of warm water is the epilimnion and floats on the cooler hypolimnion (Davis \& Cornwell, 2006; Doods, 2002). De-stratification will occur if the temperature of the total water body is $3.9^{\circ} \mathrm{C}$ (Doods, 2002), or when storms and wind mix the water. The mixing by wind is minimal in a rainwater tank, but mixing by inflow could occur depending on the storm intensity and depth of water in the tank. Australia also has reasonably high temperatures. Cool temperatures resulting in rainwater tank water cooling to $3.9^{\circ} \mathrm{C}$ are likely to only occur at high elevations or during extreme winters in Western Sydney or in the high altitude areas of New South Wales and Victoria, for example in the Blue Mountains and the Snowy Mountains. The epilimnion promotes Brownian motion, due to the higher temperatures and is likely to be influenced by inflows causing turbulence. In addition, the movement between layers is mainly molecular diffusion, thereby creating chemical and physical gradients (Doods, 2002). These result in higher chemical and biological activity, and higher concentrations in the upper layers of the water column in comparison to the lower layers. The higher concentrations and warmer temperatures in the epilimnion also support the growth of micro-organisms, and therefore biofilm growth on the air/liquid interface is likely to occur (Parker \& Barson, 1970).

The biofilm surface layer may be between 0.1-10 $\mu \mathrm{m}$, but divers significantly from the remainder of the water body (Characklis \& Cooksey, 1983; Sigee, 2005). Biofilms are defined as "microbial cells, attached to a substratum and immobilised in a three dimensional matrix of extra cellular polymers enabling the formation of an independent functioning ecosystem homeostatically regulated" (Percival et al., 2000, p. 61). These biofilms consist of $50 \%$ to $90 \%$ of Extracellular Polymeric Substances (EPS) and can provide a number of benefits, including (but not limited to) the absorption of nutrients, microbes and heavy metals, protection of temperature changes, desiccation and mediation by protozoa (Ancion et al., 2010; Bester et al., 2010; Characklis \& Cooksey, 1983; Percival et al., 2000; Sigee, 2005). The biofilms have a continuous growth cycle and have been shown to protect natural systems against pollution, but are very susceptible to the flow and turbulence of the liquid (Blanchard \& Syzdek, 1970; Percival et al., 2000). Biofilm formation was shown to be favoured during non-optimal microbial growing conditions (Landini, 2009) and growth often start off as small micro-colonies (Walker et al., 1995) attached to the tank, pipe walls or sediments (Characklis \& Cooksey, 1983; Characklis \& Marschall, 1990). The biofilms can form on the air/liquid and solid/liquid interfaces (Marshall, 1980), but the formation is also dependent on van der Waals, electrostatic and steric forces (Van Houdt \& Michiels, 2010).

It is expected that these biofilms exist on the air/liquid interface of the rainwater tank and the solid/liquid interface within the rainwater tank, pipes and in bioretention systems (Blanchard \& Syzdek, 1970; Characklis \& Marschall, 1990; Flemming, 1993; Hermansson \& Dahlbäck, 1983; Sawyer et al., 2010; Spiers et al., 2003; Spinks et al., 2003). The velocity of flow within the rainwater tank itself is slow, even when it is raining and when the tank is utilised. It is, therefore, expected that the detachment of biofilms and microbes is minimal inside the tank (Spinks et al., 2003). The biofilms formed on the air/liquid interface provide the bacteria access to oxygen from the atmosphere and nutrients from the liquid (Spiers et 
al., 2003); however, when the tank is full, it is expected that the air/liquid interface biofilm is removed from the tank through the overflow and thereby increasing the pollutants in the overflow. This allows the water to age and therefore ensures a better water quality within the tank. This however, does not take into consideration the impact of this biofilm in discharges on the receiving waters. The air/liquid interface was tested in a recent study by the authors in Western Sydney to determine if a difference was present in water samples from the bottom of tank and the overflow, thereby investigating if notable stratification occurs in the rainwater tanks.

A sample of the water at the top of two rainwater tanks were taken in the Western Sydney study and tested for E. coli, TC and TTC, Enterococcus sp. and HPC (van der Sterren, 2011; van der Sterren et al., 2010a). All microbiological results for top of the tanks for the same week as the tanks and overflow samples were higher than results from the overflow and tank samples. The water surface was determined to contain an average of $143 \mathrm{cfu} 100 \mathrm{~mL}^{-1}$ Enterococci spp., which was significantly higher than the $7 \mathrm{cfu} 100 \mathrm{~mL}^{-1}$ recorded in the tap sample. All these results showed higher readings in all microbes test in the overflow than in the tank samples, which has been theorised by Coombes et al. (2002; 2000b) to support a microlayer. This is further supported by theory of biofilms (Percival et al., 2000). It is considered critical to test the overflow during rainwater tank water quality studies to determine the long-term effect on overflow water quality, because of the biofilm growth on the air/liquid interface or the effect of chemical gradients and investigate their effect on the receiving waters.

\subsection{Water quality within the rainwater tank}

The heavy metal results of the tank samples can vary significantly between the sites and can be above the ADWG (NHMRC \& NRMMC, 2004). Aluminium concentrations were found to be above the ADWG ((NHMRC \& NRMMC, 2004)) for galvanised roofs and tanks and below the ADWG for concrete tanks in a yearlong water quality study in Western Sydney (van der Sterren, 2011; van der Sterren et al., 2010b) and this supported the findings of Berdhal et al. (2008), Föster (1996, 1999) and Magyar et al. (2007; 2008).

The aluminium concentrations in water at sites with galvanized roofs and tanks are expected to be higher than those from those sites with plastic or concrete systems (BlueScope Steel, 2010; Wight et al., 2000), because of the zinc or zinc-aluminium alloy protective layers. The aluminium concentration could also be linked to location and usage of the tanks, as a high water use household is more likely to expose the inside of the tank to atmosphere due to the higher rate of drawdown on the tank. This drawdown could expose the inside of the tank more frequently to oxygen, thereby likely causing an increase in the rate of corrosion (Askeland, 1998; Berdhal et al., 2008). The aluminium concentration determined in the Western Sydney research study were lower than those of Sorenson et al. (1974) in the United States of America (USA), but similar results were found by Herngren et al. (2005) on streets in Brisbane.

Roofs made of Zincalume ${ }^{\circledR}$ can also show elevated levels on zinc in the tank water. The coating on Zincalume ${ }^{\circledR}$ is $55 \%$ aluminium, $43.5 \%$ zinc and $1.3 \%$ silicon (BlueScope Steel, 2010). The zinc concentrations of tanks samples on sites with galvanised materials were significantly higher $(p<0.05)$ than those sites without these materials and were above the 
recommended guidelines of $3 \mathrm{mg} \mathrm{L}^{-1}$ (NHMRC \& NRMMC, 2004). The higher levels of zinc in tank samples are likely due to the protective layer that contains zinc, which can cause the higher zinc concentrations in these tanks. The risk of zinc pollution can be significantly reduced using a concrete or plastic tank (enHealth Council, 2004; NRMMC et al., 2009a). The zinc concentrations in the Western Sydney study were similar to the roof run-off results found by Thomas and Greene (1993), and Herngren et al. (2005). The Western Sydney study does not support the finding by Duncan (1999) who obtained a zinc concentration of $10.2 \mathrm{mg}$ $\mathrm{L}^{-1}\left( \pm 5 \mathrm{mg} \mathrm{L}^{-1}\right)$, which is higher than the Western Sydney results $\left(\mu_{\text {all }}=2.63 \mathrm{mg} \mathrm{L}^{-1}\right)$.

Rainwater tank catchment roof areas should not contain lead flashing, especially if the harvested water is to be used for consumption purposes (Cuncliffe, 1998; enHealth Council, 2004; NRMMC et al., 2009a). Sites containing some lead flashing on the rainwater catchment area show elevated levels of lead (Magyar et al., 2007; 2008; O'Connor et al., 2009; van der Sterren, 2011; van der Sterren et al., 2010b). Sites without lead flashing, but with Poly Vinyl Chloride (PVC) pipes can also show elevated levels of lead concentrations (Magyar et al., 2007; 2008; O'Connor et al., 2009; van der Sterren, 2011; van der Sterren et al., 2010b). Lead concentrations are of particular concern, when the residents use their tank for all in-house purposes, including consumption. Magyar et al. (2007; 2008) and O'Connor et al. (2009) found similar lead values in rainwater tank water in Victoria as van der Sterren (2011) found in Western Sydney. Duncan (1999) also showed lead concentration in roof run-off to be on average $0.054 \mathrm{mg} \mathrm{L}^{-1}\left( \pm 5.01 \mathrm{mg} \mathrm{L}^{-1}\right)$. The results collected in the Western Sydney study $\left(\mu_{\text {Tall }}=0.009 \mathrm{mg} \mathrm{L}^{-1}\right)$ were similar to other studies in Australia (Magyar et al., 2007; 2008; O'Connor et al., 2009) and are therefore, not considered unusually high.

The copper concentrations for all tanks tested in the Western Sydney study $\left(\mu_{\text {T-all }}=0.221 \mathrm{mg}\right.$ $\mathrm{L}^{-1}$ ) were well below the ADWG (NHMRC \& NRMMC, 2004), but all tank samples had a hardness falling into the soft range, which is likely to result in corrosion of copper pipe lines. Sites containing concrete tiles or a concrete tank can be beneficial for the users, as the higher hardness reduces copper corrosion. A higher hardness would be beneficial to all sites in the Western Sydney study, especially because the ADWG (NHMRC \& NRMMC, 2004) suggest that a good hardness is between 60 and $200 \mathrm{mg} \mathrm{L}^{-1} \mathrm{CaCO}$, which was not met by any of the samples on any of the sites.

Total Nitrogen is an important pollutant for receiving water bodies, but in respect to drinking water, the ADWG (NHMRC \& NRMMC, 2004) have made recommendations in regards to nitrate, nitrite and ammonium. The tank samples in the Western Sydney study indicated nitrate to be as low as $0.001 \mathrm{mg} / \mathrm{L}$ in the tank water (van der Sterren, 2011; van der Sterren et al., 2010b). This is significantly different to the roof catchment study conducted by Evans et al. (2006), who found nitrate concentrations between 0.31 and $4.63 \mathrm{mg} \mathrm{L}^{-1}$. The results are similar to the findings by Nicholson et al. (2010), whom studied roof catchment in the United States of America (USA). The long-term recommended trigger value for Total Phosphorous (TP) in collected roof run-off used for irrigation is $0.05 \mathrm{mg} \mathrm{L}^{-1}$. This can be increased to $0.2 \mathrm{mg} \mathrm{L}^{-1}$ if algal blooms in their irrigation system are acceptable (NRMMC et al., 2009a). The RWG (NRMMC et al., 2009a) indicates that it is not practical to reduce the TP concentrations in roof water for domestic applications. The average TP concentrations in the tap samples in the Western Sydney study were $0.18 \pm 0.20 \mathrm{mg} \mathrm{L}^{-1}$, which is above this guideline. The results were similar to those found by Duncan (1999) $\left(0.15 \pm 1.95 \mathrm{mg} \mathrm{L}^{-1}\right)$ and slightly below the roof run-off TP concentrations found by Miguntanna (2009) (1.85 mg L-1). 
The microbiological contamination in tanks used for drinking water must have minimal pathogenic contaminants (enHealth Council, 2004). The ADWG (NHMRC \& NRMMC, 2004) states that E. coli concentrations should not be detected and the enHealth guidelines indicate that the microbial quality of rainwater tank water is 'not as good as urban water supplies' (enHealth Council, 2004, p. 2). E. coli was detected above $1 \mathrm{cfu} 100 \mathrm{~mL}^{-1}$ for at least $75 \%$ of the tank samples in the Western Sydney study. High enumeration of E. coli was attributed to low water levels and long antecedent dry periods, resulting in an increased concentration of faecal contamination levels in the roof run-off and tank water. Lower water levels reduce the effect of dilution and the longer antecedent dry period increases the likelihood and build-up of faecal contamination from wildlife deposited onto the roof. In addition, the low water levels can potentially cause significant mixing of the water column as a result of a rainfall event. It is possible that a biofilm or the air/liquid interface are broken up and mixed throughout the small water column during low water levels and a rainfall event.

The mixing of the water column could potentially increase faecal contamination at the bottom of the tank. It has been suggested that a rainwater tank should not be grossly overdesigned to ensure that the biofilm is removed from the tank on a regular basis (van Olmen, 2009). This could be done by ensuring that the roof size and usage of the water is sufficient for the site, thereby finding a balance between the formation and cleaning out of the biofilm or air/liquid interface. The results of the enumeration of $E$. coli in the Western Sydney study showed lower concentrations than reported by McCarthy et al. (2008) in stormwater run-off (50 to $34,770 \mathrm{cfu} 100 \mathrm{~mL}^{-1}$ ). The difference is attributed to the different surface areas contributing to the stormwater run-off tested by McCarthy et al. (2008). Roofs are considered to have lower concentrations of $E$. coli than other impervious areas. The enHealth guidelines (2004, p. 12) also indicate that there is 'no measurable difference in rates of gastrointestinal illness in children who drank rainwater [sic. harvested roofwater] compared to those who drank mains water', but also indicates that those who are immunocompromised are at a much greater risk.

The turbidity in tank water varies with location and some sites show a greater variation in turbidity due to the location and size of the tank (Thomas \& Greene, 1993). The Western Sydney study showed exceedance of the turbidity guidelines from $2 \%$ to $33 \%$ of the samples taken from the tanks. This is in contrast with the results of Mobbs (1998), where the rainwater tank did not exceed the ADWG (NHMRC \& NRMMC, 2004) at all throughout a year of monthly sampling. It should be considered that testing was conducted on a weekly basis for the Western Sydney study, instead of monthly as in Mobbs (1998) and as settlement of solids is often associated with turbidity, this could give different results than monthly grab samples. The increases in turbidity from the tank samples can be attributed to the tanks not being used. When users in the Western Sydney study were on extended leave, the water quality test results showed outliers and when irrigation was not required, an increase in turbidity levels was noted. The second attribute influencing the turbidity levels is the impact of rain on the volume remaining in the tank. Han and Mun (2008) suggest using a $3 \mathrm{~m}$ deep tank to reduce the impact of rainfall on the mixing in the tank. Smaller tanks having a high water use and drawdown can result in low water levels on a regular basis. During rainfall events, the rain is likely to disturb the sediment in the bottom of the tank if the water levels are low. Other contributors to elevated turbidity levels have been the dust storm of 23 September 2009 in Sydney and the impact of runoff containing leaf litter (see Section 4.3). 
The Dissolved Oxygen in the Western Sydney study was in the acceptable range for the ADWG (NHMRC \& NRMMC, 2004), but for one tank in the study, the DO was mainly below the recommended guideline of $85 \%$ saturation (HNMRC \& NRMMC, 2004). This could be an indication of more oxygen consuming processes taking place in the tank, for example, corrosion and microbial growth, but Chemical Oxygen Demand and Biological Oxygen Demand were not tested for in the Western Sydney study and therefore this hypothesis cannot be confirmed.

The $\mathrm{pH}$ was expected to be approximately 6.5 for the tank water (Coombes et al., 2000b; Duncan, 1999; Herngren et al., 2005; Thomas \& Greene, 1993) and the average results for the sites containing galvanised materials in the Western Sydney study were not statistically different from this $\mathrm{pH}(\mu \neq 6.5, \mathrm{p}>0.05)$. The sites containing concrete were slightly higher than this, but still within the ADWG (2004) (HNMRC \& NRMMC, 2004). The effect of materials on the $\mathrm{pH}$ of the tank samples was also presented by Thomas and Greene (1993) and Mendez et al. (2011). The main cause for the $\mathrm{pH}$ increase in concrete roofs was attributed to efflorescence (Berdhal et al., 2008). Calcium hydroxide reacts with carbon dioxide in the air producing calcium carbonate, which is transported into the tank during a rain event. The calcium carbonate in the tank dissolves and neutralises the $\mathrm{pH}$. The results for $\mathrm{pH}$ found in the Western Sydney study were higher than Duncan (1999) (5.7 \pm 1.1$)$, but similar to Thomas and Greene (1993) (6.8 to 7.0). Duncan (1999) analysed values from around the world, which could have brought the mean result down due to acid rain in the Northern Hemisphere. Bridgman et al. $(1989 ; 1988)$ indicated that severity of acid rain in Australia and New Zealand is significantly lower than other parts of the world, which could explain the higher readings in the Western Sydney study and by Thomas and Greene (1993) in comparison to Duncan (1999).

The conductivity concentrations were expected to be between 15 and $297 \mu \mathrm{S} \mathrm{cm}-1$ (Camp Scott Furphy Pty Ltd, 1991; Herngren et al., 2005; Thomas \& Greene, 1993). The recorded results from the Western Sydney study fell mostly within this range and any outliers were attributed to extremely low water level. Thomas and Greene (1993) discussed that the higher conductivity was likely to be the result of concrete on their sites, which is supported by the results from the Western Sydney Study.

In summary, the materials of the rainwater tank and roof largely govern the water quality within the rainwater tank. The galvanised steel (and Zincalume ${ }^{\circledR}$ or Colourbond ${ }^{\circledR}$ ) roofs and rainwater tank are likely to add significant concentrations of aluminium and zinc to the water supply, as the aluminium and zinc coating is the sacrificial layer. The polypropylene rainwater tank, PVC piping and lead flashing increase the lead concentrations within the rainwater tank, whilst concrete increases the hardness and conductivity in the rainwater tank. A lower hardness can also increase the scaling and therefore the concentration of copper in the rainwater tank and plumbing.

\subsection{Water quality of the overflow}

A very limited amount of data is available for overflow water quality in the literature. Most rainwater tank water quality testing has focused on the potable or non-potable quality of the harvested tank water. In regards to stormwater management, the overflow quality is of a much greater concern, as it is often directly connected to the receiving drainage system. A 
study on rainwater tank water quality and quantity discharges has been conducted in Australia, in which the first $2500 \mathrm{~mL}$ of overflow was tested (van der Sterren, 2011; van der Sterren et al., 2010a). The parameters analysed were DO, pH, turbidity, conductivity, temperature, TN, TP, aluminium, copper, lead, zinc, E.coli, Enteroccocus spp., TC and TTC, which give an indication of the potential water quality of overflows from rainwater tanks. This section summarises the results of the recent study in Western Sydney(van der Sterren, 2011; van der Sterren et al., 2010a) and contrasts the results to the tank samples taken at the same time from the same sites. The overflows tested in the Western Sydney study had significantly greater pollutant loadings than the tank sample itself, which is hypothesised to be the result of the epilimnion characteristics of the air/liquid interface, the potential of biofilm growth or the microlayer on the air/liquid interface, as discussed in Section 4.1.1

Statistically the mean values and distributions of conductivity, copper hardness, lead, $\mathrm{pH}$ and turbidity were found to be similar $\left(\mu_{\mathrm{T}} \neq \mu_{\mathrm{O}}, \mathrm{p}>0.05\right)$ between the tank and overflow samples, but aluminium and zinc standard deviations of the tank and overflow samples were significantly different $\left(\sigma_{T} \neq \sigma_{O}, p<0.05\right)$. The concentrations for aluminium (min $\mathrm{O}$ all $=0.020 \mathrm{mg} \mathrm{L}^{-1}$ ) were all above $0.8 \mu \mathrm{g} \mathrm{L}^{-1}$, which is above the guideline for freshwater of 55 $\mu \mathrm{g} \mathrm{L} \mathrm{L}^{-1}$ (ANZECC \& ARMCANZ, 2000a, b). Sites containing galvanised roofs recorded higher readings for aluminium than those without. The majority of the lead results for the overflow $\left(\right.$ min $\left._{\text {Oall }}=0.001 \mathrm{mg} \mathrm{L}^{-1}\right)$ were above the AFWG (ANZECC \& ARMCANZ, 2000a, b) guideline of $34 \mu \mathrm{g} \mathrm{L} \mathrm{L}^{-1}$. A greater variation was observed on sites that contained lead flashing on the roof and conventional PVC downpipes.

The zinc concentrations for the overflow samples had higher concentrations for two sites as a result of the galvanised roofs and tank. All recorded zinc (mino-all $=0.050 \mathrm{mg} \mathrm{L}^{-1}$ ) results were above the AFWG (ANZECC \& ARMCANZ, 2000a, b) of $8 \mu \mathrm{g} \mathrm{L} \mathrm{L}^{-1}$. The RWG (NRMMC et al., 2009a) indicate that the zinc concentrations in water stored from zinc coated roofs exceeded the long and short term trigger values in the AFWG (ANZECC \& ARMCANZ, 2000a, b) and can be toxic to species. The RWG (NRMMC et al., 2009a) recommend low irrigation rates to protect sensitive plants and to minimise contamination of the soils. This would mean that the overflow discharge should be treated using best management stormwater treatment techniques prior to discharging it into the existing drainage system.

The copper concentrations in the overflow also varied, but showed a narrower distributions and similar results between overflows. A comparison of the mean copper concentrations indicated that at $95 \%$ confidence interval of the mean values $\left(\mu_{\text {all }}=0.081 \mathrm{mg} \mathrm{L}^{-1}\right)$ were similar in the Western Sydney study, but all results were above the AFWG (ANZECC \& ARMCANZ, 2000a, b). According to the RWG (NRMMC et al., 2009a) copper concentrations greater than $0.2 \mathrm{mg} \mathrm{L}^{-1}$ can be toxic to plants, which occurred occasionally in the overflow samples, thereby posing a potential threat to sensitive plants growing in the overflow discharge path. The high values for the copper concentration occurred on the same day as those outliers for lead and zinc concentrations in the results. It is hypothesised in the Western Sydney study (van der Sterren, 2011) that the humidity and warmth of summer increases the degradation, as identified by Berdahl et al. (2008), thereby increasing the pollutant wash-off.

In addition, a high rate of drawdown can also increase the corrosion, because of wetting, drying and exposure to oxygen on the inside of the tank. It should be noted that the 
hardness of overflows tested in the Western Sydney study were below the AFWG (ANZECC \& ARMCANZ, 2000a, b) criteria of $30 \mathrm{mg} \mathrm{L}^{-1} \mathrm{CaCO}$, which allows the heavy metals guidelines to be applied to the test results. All the hardness results were also below the recommended ambient in-stream guideline of lowland rivers (ANZECC \& ARMCANZ, 2000a, b). Sites containing concrete tanks and tiled roofs showed higher hardness concentrations in the overflow, just like the tank samples in the Western Sydney study.

The $\mathrm{pH}$ values of the overflows can have an impact on receiving waters, however, dilution of the overflows through the stormwater system, which is mostly concrete, could increase the $\mathrm{pH}$ and reduce the risk to the receiving waters. The AFWG (ANZECC \& ARMCANZ, $2000 \mathrm{a}, \mathrm{b}$ ) requires the $\mathrm{pH}$ to be in between 6.5 and 9.0 for inland rivers, but results indicate average higher values than the minimum guideline for sites containing concrete. This is supported by the findings from Thomas and Greene (1993), whom also found elevated $\mathrm{pH}$ results when concrete was used as a catchment area. The conductivity of the overflows is recommended to be below $300 \mu \mathrm{S} \mathrm{cm}^{-1}$ (ANZECC \& ARMCANZ, 2000a, b). The conductivity results in the overflow samples indicate that the conductivity was higher in those samples from sites with concrete than those without concrete.

E. coli, TTC, TC and Enterococci spp. counts can vary significantly between different sources and values above the guideline can be expected in rainwater tanks (Evans et al., 2006; Richardson et al., 2009). The E.coli enumeration from the overflows in the Western Sydney study showed a high variation. The enumeration of E.coli exceeded the primary contact standard for faecal coliforms (150 cfu $\left.100 \mathrm{~mL}^{-1}\right)$ and one sample exceeded the secondary contact guideline (150-1000 cfu $100 \mathrm{~mL}^{-1}$ ) (ANZECC \& ARMCANZ, 2000a, b). The results of Enterococcus spp. enumeration also exceeded the secondary contact guidelines in the AFWG (ANZECC \& ARMCANZ, 2000a, b).

The variation in the enumeration of the E. coli and Enterococcus spp. may be due to discharge volume, time elapsed between different storm events, and environmental condition, and the total indicator organisms in the run-off entering the tank during an event. The higher readings were found to occur in summer, which was similar to the findings by van Olmen (2009), who indicated that higher temperatures in the water may potentially increase the enumeration of indicator organisms.

The microbiological and nutrient analysis showed that an epilimnion, microlayer or biofilm could exist. As for the microbial and nutrient concentrations, the tank samples were significantly lower than the overflow samples. The E. coli and Enterococcus sp. counts show significantly higher counts in the overflows and were considerably higher than the outliers for the tank samples. In addition, the tank outliers were all within the variation of the overflows and occur after a significant rainfall event or during low water levels. This further supports the possibility of mixing of the water column and biological gradients discharging through the overflow. It should be noted that $50 \%$ of the overflows are above the secondary contact guideline of 230 Enterococcus sp cfu $100 \mathrm{~mL}^{-1}$ (ANZECC \& ARMCANZ, 2000a, b).

All mean overflow temperatures were within the range of $15^{\circ} \mathrm{C}$ to $23^{\circ} \mathrm{C}$ with some outliers in summer and some lower temperatures in winter, which were slightly higher than the tank samples. Thermal pollution is, therefore, considered not to be a fundamental issue for the overflow from rainwater tank; however, if all urban areas are considered, thermal pollution of receiving waters may be significant. The heat exchange laws support the growth of 
biofilms or microlayer at the air/liquid interface, as the direct contact between the water surface and the air is likely to warm up the water at the surface more than the main water body within the tank (Doods, 2002). There is direct contact between the air and liquid at the top of the tank, whilst the main body of the tank has indirect contact with the air. More heat is transferred through air/liquid interface than through the air-solid-liquid interface (tank wall). Furthermore the first $2500 \mathrm{~mL}$ of overflow was collected, which is a smaller volume than the tank and therefore after collection, more than likely to have a greater variation in temperature until removed from site as the thermal exchange laws are dependent on mass and thermal conductivity (Askeland, 1998; Young et al., 2004). The temperature and volume in the collection bottle would also affect the DO, as the re-aeration rate of oxygen is dependent on temperature, velocity and water depth (Davis \& Cornwell, 2006).

The DO concentrations were highly variable and mostly above the guideline (ANZECC \& ARMCANZ, 2000a, b). Some of the results were below the $7.6 \mathrm{mg} \mathrm{L}^{-1}$ minimum limit. This indicates that DO in the overflow should be increased prior to discharge into receiving rivers, which often occurs as a result of flow velocity and turbulence through the drainage system. The top of the tank had a higher DO content than the bottom because of the reaeration is dependent on the depth which causes a temperature gradient (Davis \& Cornwell, 2006; Doods, 2002). This higher DO concentration at the air/liquid interface and in the overflow, as a result of the gradients, combined with increases in water temperature could potentially sustain the microbes, thereby resulting in potential higher counts. In addition, when overflows occur, the rainfall coming into the rainwater tank also contains microbes, further increasing the potential survival of indicator organisms and therefore pathogens in the rainwater tank.

The TP concentrations $\left(\mu_{\mathrm{o}-\text { all }}=0.976 \mathrm{mg} \mathrm{L}^{-1}\right)$ however, were all above the AFWG (ANZECC \& ARMCANZ, 2000a, b) (0.050 $\left.\mathrm{mg} \mathrm{L}^{-1}\right)$ and RWG (NRMMC et al., 2009a). Outliers were attributed to the eucalyptus blossom and other plants in the area. According to the RWG (NRMMC et al., 2009a), the short-term impact on soils for phosphorus contamination is low. It is suggested that phosphorous levels be reduced by using bio-retention and filtration systems to minimise the effect of phosphorus contamination on receiving waters. The overflow from these rainwater tanks should, therefore, be directed to a filtration or retention system to minimise wash-off of $\mathrm{TP}$ to the receiving water bodies. All of the nitrate concentrations were well below the AFWG (ANZECC \& ARMCANZ, 2000a, b) $\left(600 \mu \mathrm{g} \mathrm{L}^{-1}\right)$ and the RWG (NRMMC et al., 2009a) (30 $\left.\mathrm{mg} \mathrm{L}^{-1}\right)$. This further supports the hypothesis that there is a microlayer or biofilm at the air liquid interface, as these layers are often formed as survival mechanisms in low nutrient environments (Landini, 2009).

Biofilm formation is promoted by non-optimal growing temperature or limited nutrients (Bester et al., 2010; Blanchard \& Syzdek, 1970; Landini, 2009). The rainwater tank has been shown to be low in nutrients and is influenced by the similar chemical gradients as a lake. The epilimnion has a limited source of DO and temperature (Chapra, 1997), thereby most likely promoting the formation of a biofilm at the air/liquid interface. The atmosphere provides another additional source reducing the strain on the microbes and allowing the formation of new cells (Bester et al., 2010; Spiers et al., 2003). The chemical and biological gradients (Chapra, 1997), the possible biofilm, as well as the pollutant run-off from the roof water can cause the overflow to have higher pollutants than the bottom of the rainwater tank. This indicates that the rainwater tank, especially larger rainwater tank, can have 
stratification and therefore should not be modelled as completely mixed tanks (or continuously stirred tanks). On the other hand, when the rainwater tank has a low volume of water, the rainfall can have a significant stirring effect on the minimal volume thereby creating a mixed tank (Chapra, 1997). There is a further need to examine the overflow from rainwater tank and their effects on the stormwater quality to understand its impact. Furthermore, detailed analysis is also required on the stratification effects in the rainwater tank and the potential of biofilm growth. These effects are considered to age and clean the water, but could have a detrimental effect on the outflow water quality of the site. It clearly highlights the need for more than one source control and using a treatment train approach, including UV treatments to control micro-organisms. Furthermore, recent research in Europe indicated that the water quality of rainwater tank improves if an overflow occurs on a regular basis, therefore indicating that a rainwater tank should not be over-designed (van Olmen, 2009).

\subsection{Impact on quality from climatic events}

Different climatic events can have impacts on the water quality of the rainwater tank. A dust storm covered Sydney and surrounds in a haze on the 23 September 2009 and deposited large amounts of fine particles onto all surfaces, which includes all roofs (Leys et al., 2009). A low intensity rainfall event occurred on the 24 September 2009 and the research conducted in Western Sydney showed high turbidity results (14.8 NTU) in the first-flush after this event. The increase of turbidity levels in the tested tanks were not detected until 6 October 2009, after a more intense rainfall event as well as settling time in the rainwater tank. The overflows also showed higher than average turbidity levels on 6 October 2009. In addition to the elevated turbidity levels, copper, TN, conductivity and hardness also showed significantly high values as a result of the storm event of 2 October 2009. Testing of the deposited dust was conducted by Radhi et al. (2010), who found that the dust contained salt particles and could be traced back to Lake Eyre Basin. The dust storm event is therefore the most likely contributor to these elevated levels. This clearly shows the needs for cleaning and maintenance of the roof after an event like this. Heavy rainfall, is the primary cause of pollutant run-off from the roof and was therefore examined here. All high values were compared to rainfall events and antecedent periods. The tank samples were more likely to show elevated levels when antecedent periods were longer, whilst overflows were more likely to show high values when there is a prolonged period between overflow events (van der Sterren, 2011).

Elevated levels and extremes were more likely to occur in the tank water quality when the antecedent rainfall event exceeded two days. The overflow, on the other hand, was more likely to contain elevated levels when the time to previous overflow exceeded 8.5 days. This is of course a guideline as events such as the dust storm or the intensity of the rainfall event can alter the high values and concentrations after a smaller antecedent period. The focus was on long term sampling (i.e. a year). The benefit of the long term testing is that the seasonal changes as well as long-term (in other words, year) impact can be examined. The antecedent time period can affect the build-up on roofs and wash-off into tanks, as high values are more likely to occur during long antecedent periods. This was previously shown to be important in pollutant build-up by other studies (Egodawatta \& Goonetilleke, 2008; Egodawatta et al., 2009; Miguntanna et al., 2010b; Sartor \& Boyd, 1972). Overflows are also more likely to contain extreme values when time intervals between overflows are longer. 


\section{Government subsidies and financial viability}

The Australian, State and local governments have a number of subsidies and grants that are provided to citizens to install a rainwater tank on their property. This section looks at the financial viability of rainwater harvesting system and these government subsidies for rainwater tanks. The amount of rebate varies from state to state and also on the size of the rainwater tank and where the water is utilised. For New South Wales, the maximum rebate is $\$ 1500$. For Australian Capital Territory and Victoria, the maximum rebate is $\$ 1000$.

A number of studies have examined the financial viability of rainwater harvesting system. These studies have looked at the financial viability of rainwater tanks by themselves, or rainwater tanks as part of an integrated catchment management method. The financial benefit of rainwater tanks as a single entity has been shown to be minimal; however, commonly reduction of cost associated with a reduction in on site detention volume and environmental benefits are often not included in these studies.

A cost benefit analysis of the financial viability of rainwater tanks is dependent on the cost of water, any subsidies and at what time the net present value is computed. In addition, the design and country of origin are also important variables in conducting a life cycle or cost benefit analysis. Roebuck and Ashley (2006) examined the life cycle costing of a rainwater tank for a school building in United Kingdom (UK) with a project life of 65 years. The longterm savings were estimated to be $£ 18,370$ opposed to $£ 122,230$ estimated by the tank supplier. They found that capital cost, maintenance cost and mains top-up cost were 31\%, $26 \%$ and $40 \%$ respectively of the total cost and argued that many of the methods of rainwater tank analysis overestimated the cost savings of rainwater tanks. Domenech and Sauri (2011) examined the financial benefit of rainwater tanks in single and multi-unit buildings in Barcelona, Spain. They found minimum pay back periods of 33 to 43 years for a single-family household and 61 years for a $20 \mathrm{~m}^{3}$ tank for multi-unit buildings. Grant and Hallmann (2003) conducted the financial viability of a 600 and a $2250 \mathrm{~L}$ rainwater tank in Australia. They found that neither tanks would create a positive return over 30 years using the 2003 water pricing. Life cycle costing of rainwater tanks for multi-storied building in Sydney using a $75 \mathrm{~kL}$ tank and for toilet, laundry and outdoor use, the cost benefit ration has been found to range from 0.64 to 1.15 for discount rates of $0 \%$ to $7.5 \%$ (Rahman et al., 2010)

Although both Spain (Barcelona) and Sydney are considered a mediteranian climate, there is a significant difference between the benefits of rainwater tanks and the pay back periods. The UK life cycle costing can expected to be very different, as the chance of rain and annual volume in the UK is higher than in Spain and Australia. These rainwater tanks are designed according to the climate and therefore affect the size, cost and use of the rainwater tank. It is therefore difficult to compare Australian data with other countries, but overall, there is a significant pay back period of a single rainwater tank and the cost-benefit analysis should take all aspects of the benefits and the cost into account.

When the financial viability of rainwater tanks are considered as part of an integrated water cycle management plan, the rainwater tanks are shown to have significant benefits to authorities. The demand on dam and mains water is significantly reduced when rainwater tanks are implemented throughout the catchment. Various studies have shown that the cost reduction by implementing rainwater tanks throughout the catchment is significant 
(Coombes \& Kuczera, 2003; Coombes et al., 2000a; Davis \& Birch, 2008; Lucas, 2009; Lucas et al., 2009). This clearly indicates that any cost-benefit analysis should not only investigate the cost and benefits of a single rainwater tank, but the cost and benefits of the whole system, including water mains upgrade, cost to the environment and reduction in cost of treating and managing stormwater.

\section{Conclusion}

Rainwater tanks are popular in Australia as a source of alternative water supply and a means of stormwater management. From a literature review and findings from a field study conducted in Western Sydney in Australia, it has been found that materials of the rainwater tanks and roof largely govern the water quality within the rainwater tanks. The overflow and first flush water quality from the rainwater tanks exceeded water quality guidelines, highlighting the needs for further treatment before discharging the water to urban stormwater systems. The water quality in the rainwater tanks does not meet the drinking water guidelines on many instances, especially during low water levels and the days immediately after a rainfall event. Under these circumstances, the tank water should be disinfected before drinking. Rainwater tanks are found to be not financially viable at lot scale given the current water price, but if all the associated benefits of rainwater tanks at catchment scales are accounted for their financial viability is likely to increase significantly.

\section{Acknowledgements}

The work presented in this Chapter would not have been completed without the assistance of Jonathan Barnes, Solomon Donald and Ian Turnbull. Thanks also to Surendra Shrestha, John Bavor, Jeff Scott, Sharon Armstrong, Rhonda Gibbons, Bert Aarts, Wayne Higgenbotham, Paul Roddy, Heidi Fitzpatrick from the University of Western Sydney. Thanks also to Turnbull Electrical Contracting, who contributed time and resources for the installations of the systems on site and the funding from the UWS office of Disabilities.

\section{References}

Ancion, P.-Y., Lear, G., \& Lewis, G. D. (2010). Three common metal contaminants of urban runoff $(\mathrm{Zn}, \mathrm{Cu} \& \mathrm{~Pb})$ accumulate in freshwater biofilm and modify embedded bacterial communities. Environmental Pollution, 158(8), 2738-2745.

Askeland, D. R. (1998). The science and engineering of materials. Cheltenham: Stanley Thornes Ltd.

Australian and New Zealand Environment and Conservation Council, \& Agriculture and Resource Management Council of Australian and New Zealand (ANZECC \& ARMCANZ) (2000a). Australian and New Zealand guidelines for fresh and marine water quality - volume 1. National Water Quality Management Strategy. Artarmon: Australian Water Association.

Australian and New Zealand Environment and Conservation Council, \& Agriculture and Resource Management Council of Australian and New Zealand (ANZECC \& ARMCANZ) (2000b). Australian and New Zealand guidelines for fresh and marine water quality - volume 2 - aquatic ecosystems - rationale and background information. Artarmon: Australian Water Association. 
Australian and New Zealand Environment and Conservation Council, \& Agriculture and Resource Management Council of Australian and New Zealand (ANZECC \& ARMCANZ) (2000c). Australian guidelines for urban stormwater management. National Water Quality Management Strategy. Artarmon: Australian Water Association.

Australian Bureau of Statistics (2010). Australia's Environment: Issues and Trends. Canberra: Australian Bureau of Statistics.

Australian Bureau of Statistics (ABS) (2011). Regional Population Growth, Australia. Canberra: Australian Bureau of Statistics.

Bach, P. M., MacCarthy, T. D., \& Deletic, A. (2010). Redefining the stormwater first flush phenomenon. Water Research, 44(8), 2487-2498.

Barry, M. E., \& Coombes, P. J. (2006). Optimisation of mains trickle topup supply to rainwater tanks in an urban setting. Australian Journal of Water Resources, 10(3), 269275.

Barry, M. E., \& Coombes, P. J. (2007). Optimisation of mains trickle topup volumes and rates supplying rainwater tanks in the Australian urban setting. Rainwater and Urban Design Conference. Sydney: The Institution of Engineers Australia.

BASIX Sustainability Unit (2009). Building Sustainability Index. Sydney: New South Wales Department of Planning.

Berdhal, P., Akbari, H., Levinson, R., \& Miller, W. A. (2008). Weathering of roofing materials - an overview. Construction and Building Materials, 22(4), 423-433.

Bester, E., Kroukamp, O., Edwards, E. A., \& Wolfaardt, G. M. (2010). Biofilm form and function: carbon activity affects biofilm architecture, metabolic activity and planktonic cell yield. Journal of Applied Microbiology, 110(2), 387-398.

Blackburn, N., Morison, P., \& Brown, R. (2010). A review of factors indicating likelihood of and motivations for household rainwater tank adoption. Stormwater 2010: National Conference of the Stormwater Industry Association. Sydney, pp. 1-10.

Blacktown City Council (2006). Blacktown development control plan 2006. Blacktown: Blacktown City Council.

Blanchard, D. C., \& Syzdek, L. (1970). Mechanisms for the water-to-air transfer and concentration of bacteria. Science, New Series, 170(3958), 626-628.

Blue Mountains City Council (2005). Better Living Development Control Plan. Katoomba: Blue Mountains City Council.

BlueScope Steel (2010). Benefits of ZINCALUME® steel.

Bridgman, H. A. (1989). Acid rain studies in Australia and New Zealand. Archives of Environmental Contamination and Toxicology, 18(3), 137-146.

Bridgman, H. A., Rothwell, R., Tio, P.-H., \& Pang-Way, C. (1988). The Hunter region (Australia) acid rain project. Bulletin of the American Meteorological Society, 69(3), 266271.

Brisbane City Council (2008). Subdivision and development guidelines - Part C water quality management guidelines. Brisbane: Brisbane City Council.

Brodie, I. M. (2007). Investigation of stormwater particles generated from common urban surfaces. Faculty of Engineering and Surveying: University of Southern Queensland.

Bucheli, T. D., Müller, S. R., Heberle, S., \& Schwarzenbach, R. P. (1998). Occurrence and behaviour of pesticides in rainwater, roof runoff, and artificial stormwater infiltration. Environmental Science and Technology, 32(22), 3457-3464. 
Camp Scott Furphy Pty Ltd (1991). Urban runoff study: Nepean-Hawkesbury Catchment Management Council.

Chapra, S. C. (1997). Surface water-quality modeling: WCB/McGraw-Hill.

Characklis, W. G., \& Cooksey, K. E. (1983). Biofilms and microbial fouling. Advances in Applied Microbiology, 29, 93-138.

Characklis, W. G., \& Marschall, K. C., eds. (1990). Biofilms. New York: John Wiley \& Sons.

Coombes, P. J. (2002). Rainwater tanks revisited: new opportunities for Urban Water Cycle Management. Newcastle: University of Newcastle.

Coombes, P. J., \& Kuczera, G. (2003). A sensitivity analysis of an investment model used to determine the economic benefits of rainwater tanks. 28th International Hydrology and Water Resources Symposium. Wollongong, Australia: Institution of Engineers Australia, pp. 243-250.

Coombes, P. J., Kuczera, G., \& Kalma, J. D. (2000a). Economic benefits arising from use of Water Sensitive Urban Development source control measures. Hydro 2000 - 3rd International Hydrology and Water Resources Symposium of the Institution of Engineers Australia. Perth, Western Australia: The Institution of Engineers Australia, pp. 152157.

Coombes, P. J., Kuczera, G., \& Kalma, J. D. (2000b). Rainwater quality from roofs, tanks and hot water systems at Figtree Place. Hydro 2000 - 3rd International Hydrology and Water Resources Symposium of the Institution of Engineers Australia. Perth, Western Australia: The Institution of Engineers Australia, pp. 1042-1047.

Cuncliffe, D. A. (1998). Guidance on the use rainwater tanks. National Environmental Health Forum Monographs, Water Series Number 3. Rundle Mall: Department of Human Services.

Davis, B. S., \& Birch, G. F. (2008). Catchment-wide assessment of the cost-effectiveness of stormwater remediation measures in urban areas. Environmental Science $\mathcal{E}$ Policy, 12(1), 84-91.

Davis, M. L., \& Cornwell, D. A. (2006). Introduction to environmental engineering. New York: McGraw-Hill.

Domènech, L., \& Saurí, D. (2011). A comparative appraisal of the use of rainwater harvesting in single and multifamily buildings of the Metropolitan Area of Barcelona (Spain): social experience, drinking water savings and economic costs. Journal of Cleaner Production, 19(1), 598-608.

Doods, W. (2002). Freshwater ecology - concepts and environmental applications. Elsevier.

Duncan, H. P. (1999). Urban stormwater quality: A statistical overview. Cooperative Research Centre for Catchment Hydrology.

Egodawatta, P., \& Goonetilleke, A. (2008). Modelling pollutant build-up and wash-off in urban road and roof surfaces. 31 $1^{\text {st }}$ Hydrology and Water Resources Symposium and $4^{\text {th }}$ International Conference on Water Resources and Environmental Research: Water Down Under 2008. Adelaide, Australia, pp. 418-427.

Egodawatta, P., Thomas, E., \& Goonetilleke, A. (2009). Understanding the physical processes of pollutant build-up and wash-off on roof surfaces. Science of the total Environment, 407(6), 1834-1841.

enHealth Council (2004). Guidance on use of rainwater tanks. In: Australian Government, ed: Australian Government Department of Health and Ageing, pp. 1-72. 
Environmental Health Branch (2008). Rainwater tanks where a public water supply is available - use of. North Sydney: Department of Health, New South Wales Government.

Evans, C. A., Coombes, P. J., \& Dunstan, R. H. (2006). Wind, rain and bacteria: The effect of weather on the microbial composition of roof-harvested rainwater. Water Research, 40(1), 37-44.

Flemming, H.-C. (1993). Biofilms and environmental protection. Water Science and Technology, 27(7-8), 1-10.

Föster, J. (1996). Patterns of roof runoff contamination and their potential implications on practice and regulations of treatment and local infiltration. Water Science and Technology, 33(6), 39-48.

Föster, J. (1999). Variability of roof runoff quality. Water Science and Technology, 39(5), 137144.

Goonetilleke, A., Thomas, E., Ginn, S., \& Gilbert, D. (2005). Understanding the role of land use in urban stormwater quality management. Journal of Environmental Management, 74(1), 31-42.

Goyen, A. G., Lees, S. J., \& Phillips, B. C. (2002). Analysis of allotment based storage, infiltration and reuse drainage strategies to minimize urbanization effects. 9th International Conference on Urban Drainage, Global Solutions for Urban Drainage:9ICUD 2002. Portland, Oregon USA: American Society of Civil Engineers, pp. 1-17.

Grant, T., \& Hallmann, M. (2003). Urban domestic rainwater tanks: Life cycle assessment. Water, 30(5), 36-41.

Griffin, D. M. J., Randall, C., \& Grizzard, T. J. (1980). Efficient design of stormwater holding basins used for water quality protection. Water Research, 14(10), 1540-1554.

Han, M. Y., \& Mun, J. S. (2008). Particle behaviour consideration to maximize the settling capacity of rainwater storage tanks. Water Science and Technology, 56(11), 73-79.

Hawkesbury City Council (2000). Development control plan 2000. Windsor: Hawkesbury City Council.

Hermansson, M., \& Dahlbäck, B. (1983). Bacterial activity at the air/water Interface. Microbial Ecology, 9(4), 317-328.

Hermansson, M., Jones, G. W., \& Kjelleberg, S. (1987). Frequency of antibiotic and heavy metal resistance, pigmentation and plasmids in bacteria of the marine air-water interface. Applied and Environmental Microbiology, 53(10), 2338-2342.

Herngren, L., Goonetilleke, A., \& Ayoko, G. A. (2005). Understanding heavy metal and suspended solids relationships in urban stormwater using simulated rainfall. Journal of Environmental Management, 76(2), 149-158.

Heyworth, J. S., Maynard, E. J., \& Cuncliffe, D. A. (1998). Who drinks what? Potable water use in South Australia. Water (Melbourne), 25(1), 9-13.

Horstman, M. (2007). 1000 year drought. In: Hiscox, M., ed. Catalyst. Australia: Australian Broadcasting Company, p. 9:38.

Landini, P. (2009). Cross-talk mechanisms in biofilm formation and responses to environmental and physiological stress in Escherichia coli. Research in Microbiology, 160(4), 259-266.

Leys, J., Heidenreich, S., \& Case, M. (2009). DustWatch report for week ending 21 September 2009. 1-6. 
Lucas, S. A. (2009). Mains water savings and stormwater management benefits from large architecturally - designed under-floor rainwater storages. 32nd Hydrology and Water Resources Symposium. Newcastle: Engineers Australia, pp. 628-640.

Lucas, S. A., Coombes, P. J., \& Sharma, A. K. (2009). Residential diurnal water use patterns and peak demands - implications for integrated water infrastructure planning. 32nd Hydrology and Water Resources Symposium. Newcastle Australia: Engineers Australia, pp. 1081-1091.

Magyar, M. I., Mitchell, V. G., Ladson, A. R., \& Diaper, C. (2007). An investigation of rainwater tanks quality and sediment dynamics. Water Science and Technology, 56(9), 21-28.

Magyar, M. I., Mitchell, V. G., Ladson, A. R., \& Diaper, C. (2008). Lead and other heavy metals: common contaminants of rainwater tanks in Melbourne. 31 st Hydrology and Water Resources Symposium and $4^{\text {th }}$ International Conference on Water Resources and Environmental Research: Water Down Under 2008. Adelaide, Australia: Institute of Engineers Australia, pp. 409-417.

Marshall, K. C. (1980). Microorganisms and interfaces. BioScience, 30(4), 246-249.

McCarthy, D. T., Deletic, A., Mitchell, V. G., Fletcher, T. D., \& Diaper, C. (2008). Uncertainties in stormwater E.coli levels. Water Research, 42(-), 1812-1824.

Melbourne Water (2005). Water Sensitive Urban Design engineering procedures: stormwater. Melbourne Australia: CSIRO Publishing.

Mendez, C. B., Klenzendorf, J. B., Afshar, B. R., Simmons, M. T., Barrett, M., Kinney, K. A., \& Kirisits, M. J. (2011). The effect of roofing material on the quality of harvested rainwater Water Research, Article in Press, 1-11.

Miguntanna, N. (2009). Determining a set of surrogate parameters to evaluate urban stormwater quality. Faculty of Built Environment and Engineering: Queensland University of Technology.

Miguntanna, N., Egodawatta, P., Kokot, S., \& Goonetilleke, A. (2010a). Determination of a set of surrogate parameters to assess urban stormwater quality. Science of the total Environment, 408(24), 6251-6259.

Miguntanna, N., Goonetilleke, A., Egodawatta, P., \& Kokot, S. (2010b). Understanding nutrient build-up on road surfaces. Journal of Environmental Sciences, 22(6), 806 812.

Mobbs, M. (1998). Sustainable house. Marrickville, Australia: CHOICE Books.

Moeller, T., Bailar, J. C., Jr., Kleinberg, J., Guss, C. O., Castellion, M. E., \& Metz, C. (1984). Chemistry with inorganic qualitative analysis. Orlando, Florida: Academic Press Inc.

National Health and Medical Research Council \& Natural Resource Management Ministerial Council (NHMRC \& NRMMC) (2004). National water quality management strategy - Australian Drinking Water Guidelines. Australian Government.

Natural Resource Management Ministerial Council, Environment Protection and Heritage Council, \& National Health and Medical Research Council (NRMMC / EPHC \& HNMRC) (2009a). National water quality management strategy - Australian guidelines for water recycling: Stormwater harvesting and reuse. Australian Government. 
Natural Resource Management Ministerial Council, Environment Protection and Heritage Council, \& National Health and Medical Research Council (NRMMC / EPHC \& HNMRC) (2009b). National water quality management strategy - Australian Guidelines for Water Recylcing (Phase 2): Augmentation of drinking water supplies. Australian Government.

Natural Resource Management Ministerial Council, Environment Protection and Heritage Council, \& National Health and Medical Research Council (NRMMC / EPHC \& HNMRC) (2009c). National water quality management strategy - Overview of the Australian guidelines for water recycling: Managing health and environmental risks 2006. Australian Government.

Nicholas, D. I. (1995). On-site Stormwater Detention: improved implementation techniques for runoff quantity and quality management in Sydney. Water Science and Technology, 32(1), 85-91.

Nicholson, N., Clark, S. E., Long, B. V., Siu, C. Y. S., Spicher, J., \& Steele, K. A. (2010). Roof runoff water quality - a comparison of traditional roofing materials. World Environmental and Water Resources Congress 2010: Challenges of Change. Providence, Rhode Island: American Society of Civil Engineers, pp. 3349-3355.

O'Connor, J. B., Mitchell, V. G., Magyar, M. I., Ladson, A. R., \& Diaper, C. (2009). Where is the lead in rainwater tanks coming from? 32nd Hydrology and Water Resources Symposium. Newcastle, Australia: Institute of Engineers Australia, pp. 653-660.

Parker, B., \& Barson, G. (1970). Biological and chemical significance of surface microlayers in aquatic ecosystems. BioScience, 20(2), 87-93.

Penrith City Council (2008). Exhibition of stage 1 planning documents. Penrith, Australia: Penrith City Council.

Penrith City Council (2010). Penrith City Council Development Control Plan. Penrith.

Percival, S. L., J. T. Walker, et al. (2000). Microbiological aspects of biofilms and drinking water. Vreeland, R. H. (ed). Boca Raton: CRC Press.

Radhi, M., Box, M. A., Box, G. P., \& Cohen, D. D. (2010). Size-resolved chemical composition of the September 2009 Sydney dust storm. Air Quality and Climate Change, 44(3), 25-30.

Rahman, A., Dbais, J., \& Imteaz, M. A. (2010). Sustainability of RWHSs in Multistorey Residential Buildings. American Journal of Engineering and Applied Sciences, 1(3), 889898.

Richardson, H. Y., Nichols, G., Lane, C., Lake, I. R., \& Hunter, P. R. (2009). Microbiological surveillance of private water supplies in England - the impact of environmental and climate factors on water quality. Water Research, 43(8), 2159-2168.

Roebuck, R. M., \& Ashley, R. (2006). Predicting the hydraulic and life-cycle cost performance of rainwater harvesting systems using a computer based modeling tool. 4th International Conference on Water Sensitive Urban Design. Melbourne: Engiener Australian, pp. 699-709.

Sartor, J. D., \& Boyd, G. B. (1972). Water pollution aspects of street surface contaminants. In: monitoring, O. o. r. a., ed. Washington: US Environmental Protection Agency, p. 236.

Sawyer, C. B., Hayes, J. C., \& English, W. R. (2010). Characterization of Escherichia coli for sediment basin systems at construction sites. World Environmental and Water Resources Congress 2010: Challenges of Change. Providence, Rhode Island: American Society of Civil Engineers, pp. 3198-3208. 
Sigee, D. C. (2005). Freshwater microbiology - biodiversity and dynamic interactions of microorganisms in the aquatic environment. Chichester: John Wiley \& Sons.

Sorenson, J. R. J., Campbell, I. R., Tepper, L. B., \& Lingg, R. D. (1974). Aluminium in the environment and human health. 8, 3-95.

Spiers, A. J., Bohannon, J., Gehrig, S. M., \& Rainey, P. B. (2003). Biofilm formation at the airliquid interface by the Pseudomonas fluroscens SBW25 wrinkly spreader requires an acetylated form of cellulose. Molecular Microbiology, 50(1), 15-27.

Spinks, A. T., Coombes, P. J., Dunstan, R. H., \& Kuczera, G. (2003). Water quality treatment processes in domestic rainwater harvesting systems. 28th International Hydrology and Water Resources Symposium. Wollongong, Australia: Institution of Engineers Australia, pp. 227-234.

Standards Australia (2006). Plumbing and drainage part 3: Stormwater drainage. In: Australian and New Zealand Standards, ed. Sydney: Australian Standards.

Standards Australia (2008). HB 230-2008 Rainwater tank design and installation handbook. In: Australian and New Zealand Standards, ed. Sydney, Australia: Standards Australia.

Sydney Water (2007). Water analysis - Typical water analysis for Sydney Water's drinking water supply. Sydney: Sydney Water.

Thomas, P. R., \& Greene, G. R. (1993). Rainwater quality from different roof catchments. Water Science and Technology, 28(3-5), 291-299.

Upper Parramatta River Catchment Trust (UPRCT), Cardno Willing (NSW) Pty Ltd, Haddad Khalil Mance Arraj Partners, \& Brown Consulting (NSW) Pty Ltd (2005). On-site stormwater detention handbook. Upper Parramatta River Catchment Trust.

van der Sterren, M. (2011). Assessment of the impact of rainwater tanks on urban run-off quantity and quality characteristics (under review). School of Engineering. Penrith: University of Western Sydney, p. 604.

van der Sterren, M., Dennis, G. R., Chuck, J., \& Rahman, A. (2010a). Rainwater tank water quality testing in Western Sydney, Australia. World Environmental and Water Resources Congress - Challenges of Change. Providence, USA, pp. 4048-4058.

van der Sterren, M., Rahman, A., \& Dennis, G. R. (2009). A case study of rainwater tank quality testing in Western Sydney, Australia. The 7th International Symposium on Ecohydraulics and 8th International Conference on Hydroinformatics Concepcíon, Chile.

van der Sterren, M., Rahman, A., \& Ryan, G. (2010b). Investigation of water quality and quantity of five rainwater tanks in Western Sydney, Australia. World Environmental and Water Resources Congress - Challenges of Change. Providence, USA, pp. 3933-3941.

Van Houdt, R., \& Michiels, C. W. (2010). Biofilm formation and the food industry, a focus on the bacterial outer surface. Journal of Applied Microbiology, 109(4), 1117-1131.

van Olmen, R. (2009). Gebruik van hemelwater in woningen - economische en ecologische analyse. Belgium: Universiteit Hasselt.

Verkerk, G., Broens, J. B., Kranendonk, W., van der Puijl, F. J., Sikkema, J. L., \& Stam, C. W. (1992). BINAS. Groningen: Wolters-Noordhoff.

Walker, J. T., Mackerness, C. W., Rogers, J., \& Keevil, C. W. (1995). Heterogeneous mosaic biofilm - a haven for waterborne pathogens. In: Lappin-Scott, H. M., \& Costerton, J. W., eds. Microbial Biofilms. Cambridge: Cambridge University Press.

White, I. (2010). Rainwater harvesting: theorising and modelling issues that influence household adoption. Water Science and Technology, 62(2), 370-377. 
Wight, I., Huddle, L., \& Mullens, R. (2000). Why any old galvanised iron won't do... The Heritage Advisor.

Wong, T. H. F., ed. (2006). Australian runoff quality - A guide to Water Sensitive Urban Design. Crows Nest: Engineers Australia

Young, H. D., Freedman, R. A., \& Ford, L. A. (2004). Sears and Zemansky's university physics with modern physics. Sydney: Pearson Education. 


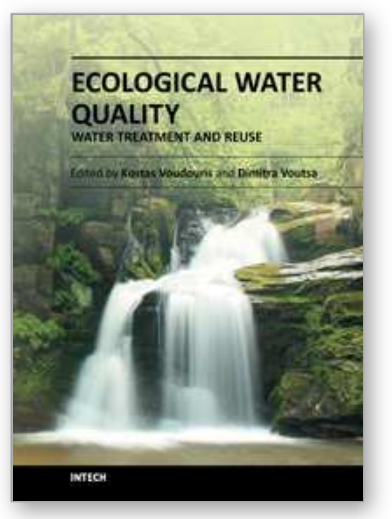

\author{
Ecological Water Quality - Water Treatment and Reuse \\ Edited by Dr. Voudouris
}

ISBN 978-953-51-0508-4

Hard cover, 496 pages

Publisher InTech

Published online 16, May, 2012

Published in print edition May, 2012

This book attempts to cover various issues of water quality in the fields of Hydroecology and Hydrobiology and present various Water Treatment Technologies. Sustainable choices of water use that prevent water quality problems aiming at the protection of available water resources and the enhancement of the aquatic ecosystems should be our main target.

\title{
How to reference
}

In order to correctly reference this scholarly work, feel free to copy and paste the following:

M. van der Sterren, A. Rahman and G.R. Dennis (2012). Rainwater Harvesting Systems in Australia, Ecological Water Quality - Water Treatment and Reuse, Dr. Voudouris (Ed.), ISBN: 978-953-51-0508-4, InTech, Available from: http://www.intechopen.com/books/ecological-water-quality-water-treatment-andreuse/rainwater-harvesting-systems-in-australia

\section{INTECH}

open science | open minds

\author{
InTech Europe \\ University Campus STeP Ri \\ Slavka Krautzeka 83/A \\ 51000 Rijeka, Croatia \\ Phone: +385 (51) 770447 \\ Fax: +385 (51) 686166 \\ www.intechopen.com
}

\author{
InTech China \\ Unit 405, Office Block, Hotel Equatorial Shanghai \\ No.65, Yan An Road (West), Shanghai, 200040, China \\ 中国上海市延安西路65号上海国际贵都大饭店办公楼 405 单元 \\ Phone: +86-21-62489820 \\ Fax: $+86-21-62489821$
}


(C) 2012 The Author(s). Licensee IntechOpen. This is an open access article distributed under the terms of the Creative Commons Attribution 3.0 License, which permits unrestricted use, distribution, and reproduction in any medium, provided the original work is properly cited. 